\title{
Fostering Second Language Development Through Play in a Multilingual Classroom
}

\author{
Susan Fraser and Patricia Wakefield
}

For three years, a study on the relationship between language and play in a preschool multilingual/multicultural setting and its significance for linguistic and social development has been carried out in Vancouver. This paper reports on one aspect of the study-strategies for fostering second language development through play.

Traditional early childhood education programs in the Western world are based on the philosophy that play is the best medium through which a child learns, grows and develops to his fullest potential. According to Froebel (1897), "Play holds the source of all that is good" for the child. The importance of play continues to be emphasized by important educational theorists, such as Piaget, who state that play provides an ideal environment for the child's development. Teachers working with preschool children are questioning how play is affected when children do not have a common language with which to communicate with one another.

Parten (1932) developed a hierarchy of play behaviours which is used to categorize play behaviour from more immature forms of social play such as parallel play to the most mature level of imaginative play, socio-dramatic play. Smilansky (1968) identified five components in socio-dramatic play: role playing, make-believe transformations, social interactions, verbal communication and persistence. Rosenblatt (1977) confirms the close relationship between language and play. He observed that children who exhibit high levels of pretend play also show complex language use.

Weikart (1978) questions whether play alone provides all children with the best environment for learning. In the Perry Preschool Project, a preschool research project in Ypsilanti, Michigan, children, especially those from disadvantaged backgrounds, appeared to progress better when teachers introduced some structure into the play environment. Sherrod, Siewart, and Cavallaro (1984) studied children who were slow in developing language and found them to be "somewhat isolated" in the typically play oriented preschool environment. They noted that a child needed a fair proficiency in language to benefit from the learning 
experiences available in a natural play situation. They compared the play of a group of language delayed five year olds with a group of normal three year old children to see whether more mature levels of play were dependent on the child's age or level of language use. They found that the older, language delayed children played at a significantly less mature level on a hierarchy of play behaviour. Language ability, therefore, appeared to affect the child's ability to engage in more mature levels of play although the authors admit that the reasons for immature play behaviour are complex and may not be entirely attributable to language development.

An important question, therefore, for teachers planning programs for children who do not speak English and come from different cultural backgrounds, is whether the traditional play oriented preschool program offered in most preschool settings, provides these children with the best program to foster their learning, particularly in the area of social and linguistic development.

Researchers in the Sexsmith ESL Demonstration Preschool in Vancouver have been studying the relationship between language and social development and the effect they have on play behaviour for the past four years (Dixon and Fraser, 1985). The preschool, for children between the ages of three and four, is administered by the Sexsmith Community School. It is situated in a settled area of the city where people from many different cultural backgrounds have made their homes. In the Sexsmith Preschool, Chinese and East Indian children form the largest majority although there are also Fijian and Filipino children included in the group. About one fifth of the children speak English as a first language, a reflection of the situation in the wider community. All children are tested using the Peabody Picture Vocabulary Test (Revised) at the beginning and end of the school year. The mean standard score for both morning and afternoon groups of children is 73 as measured on the Peabody scale. This suggests that the average child in the group is a little more than one year behind in his ability to understand English when compared to typical English speaking children. The children's individual scores, however, may range from $0-120$, that is, from a virtual absence of knowledge of English to a vocabulary well above age level.

The observations of children's play at the Sexsmith preschool have shown that when a group of children without a common linguistic or cultural background try to develop play at the socio-dramatic level of play using Smilansky's definition, they are seldom able to sustain it for more than a brief period. This may be due to both linguistic and cultural factors. Acording to Garvey (1974) it is essential that children share a common script or narrative to be able to play effectively at the level of socio-dramatic play. This element may not be present when children 
come from a wide variety of cultural backgrounds which is the case at Sexsmith.

Different values implicit in the child-rearing practices in the children's families may also play a part. Lee (1984) noted that educational play, like spontaneous play, should be player centered, i.e. "player initiated, player paced and player styled." It may be that not all children have been encouraged to show the same degree of self assertion, initiative and independence in thought and action that many preschool teachers expect children to produce to gain the most benefit from the play-oriented programs offered in most preschool programs in Canada.

Although most preschools present children with good linguistic and social experiences in a play-oriented program, this type of program may be inadequate for children who have a limited ability to speak English and a different cultural background. It seems essential, therefore, that a reassessment of the typical play-oriented preschool program and the role of the teacher during freeplay is needed to modify programs, if necessary, to match the needs of children from different linguistic and cultural backgrounds.

One aspect of the research at the Sexsmith ESL Demonstration Preschool has been an investigation of the effect the teacher's intervention in play has upon the number of English language utterances made by the children and the number of incidents of socio-dramatic play they produce. Four typical preschool activities based on community themes were planned in the dramatic play area of the room. This area was rearranged to represent a grocery store, a post office, a hospital and a zoo. Each theme was carefully introduced to both the morning and the afternoon group of children by either taking the children on a field trip or inviting a visitor to come to school. In this way the teacher hoped to increase the children's awareness and motivate their interest in the community theme. She also hoped to help the children develop a common script or narrative based on these themes so they could participate in socio-dramatic play later.

Each group of children was videotaped while they were involved in dramatizing the theme in the dramatic play corner of the classroom. At these times activities usually available during free play time were kept to a minimum and appropriate props were available to encourage the children to focus their play around the theme. During the four episodes filmed of the morning group the teacher did not intervene in the children's play. In the afternoon, she varied the level of intervention from playing a minor role to playing a major role in the children's play. For instance, she played the role of a patient in the hospital (minor role), the mailman in the post office (major role), and acted merely as an "anchor" during the zoo play by sitting on the floor, making suggestions and providing the children with labels for the animals and objects being 
used as they carried out the theme. The researchers also followed the role played by an English speaking child when he became actively involved in the dramatic play.

On completion of the videotaping of the eight episodes, the tapes were transcribed and all the children's English language utterances and episodes of socio-dramatic play were tallied. The scores were compared to the number of times the teacher spoke to the children and intervened in their play. The results are shown in Figures 1 and 2. Figure 1 shows the relationship between the amount of teacher intervention in the children's play and the number of incidents of socio-dramatic play produced by the children.

In examining the results shown in Figure 1, one can see that overall, the number of English language utterances made by the children increased in proportion to the number of times the teacher interacted verbally with the children during their play. In the post office theme $(\mathrm{g})$, for instance, the children produced more English language when the teacher made more verbal interactions and played a dominant role as the mailman. The most dramatic increase in the number of verbal interactions made by the children without teacher involvement in the play, occurred when the English speaking child, Robbie, around whom the play often centered, became involved in the play based on the zoo theme (e). His verbal interaction raised the number of utterances to the highest level of 113, although 40 of these were made by Robbie, himself. He played an important role in the play by supplying the other children with English labels, "That's not a moose, that's a horse," and by eliciting language through asking questions such as, "What do foxes eat?"

The effect of the teacher's intervention in socio-dramatic play is shown in Figure 2. The level of teacher intervention in the children's play did not appear to affect to any great extent the number of sociodramatic incidents that occurred in the play. However, when the teacher dominated the play in her role as the mailman (although the most successful for eliciting language) it may have had the effect of decreasing the number of socio-dramatic play incidents produced by the children. In this case the number of incidents decreased from fourteen (minor role as a patient in the hospital) to eight (major role as mailman in the post office).

As was the case for verbal interactions, the most successful episode, in terms of number of socio-dramatic incidents, occurred when the popular English speaking child became involved in the play. He not only acted as a catalyst to the play but he also gave the group a sense of cohesion by refocussing the group's attention on the theme by making statements such as, "We are playing zoo, O.K." and later when action began to lag he brought them back on task by saying, "We have 


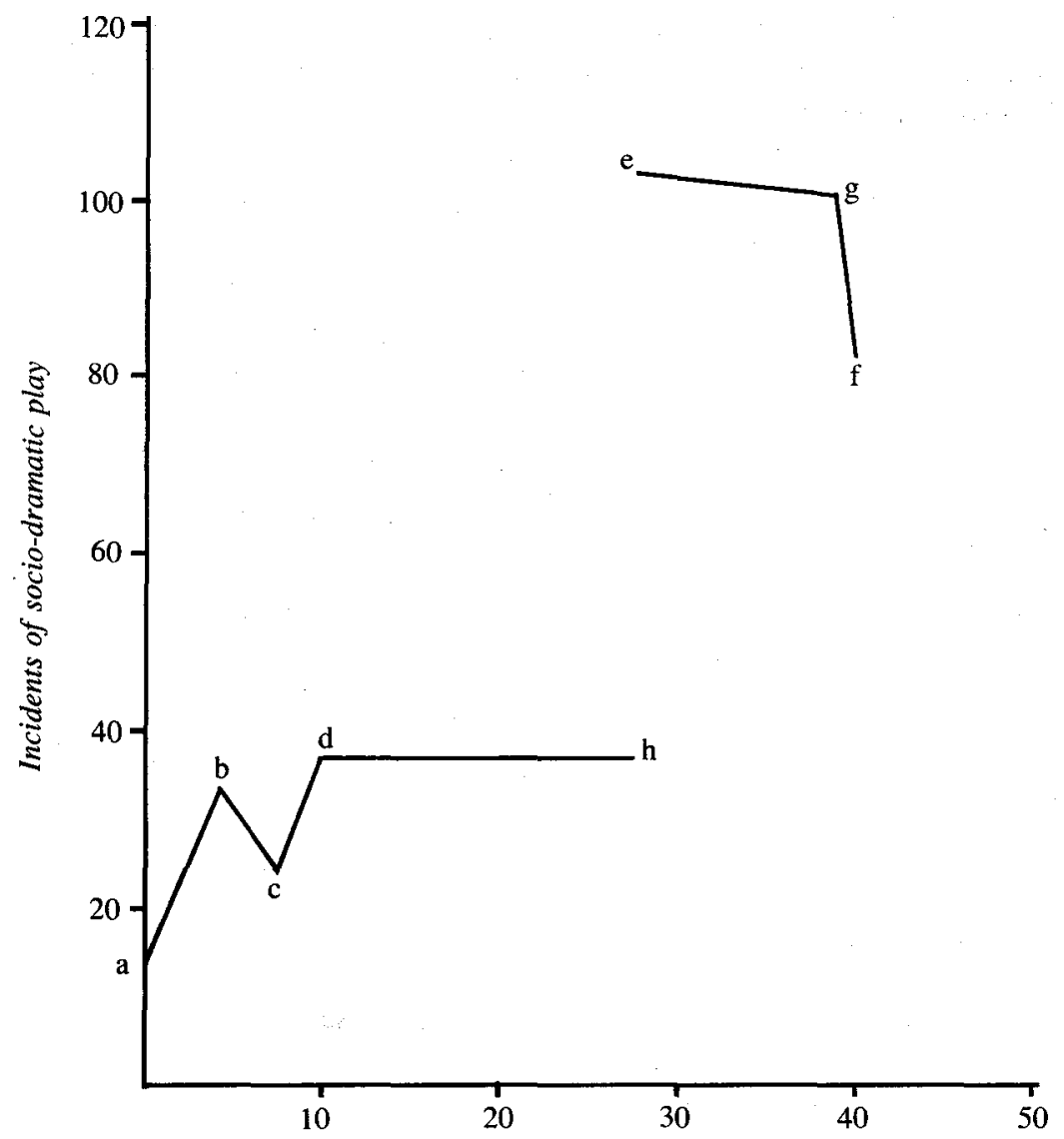

Number of verbal interactions made by the teacher

Figure 1. Relationship between the teacher's verbal interaction with the children and the number of English language utterances made by the children.

$\begin{array}{clll}\text { KEY } & \text { a - hospital } & \text { (a.m. group) } & \\ \text { b- grocery } & \text { (p.m. group) } & \\ \text { c - grocery } & \text { (a.m. group) } & \\ \text { d - post office } & \text { (a.m. group) } & \\ \text { e - zoo } & \text { (a.m. group) } & \text { English model involved in play } \\ \text { f }- \text { zoo } & \text { (p.m. group) } & \text { Teacher acts as anchor } \\ \text { g- post office } & \text { (p.m. group) } & \text { Teacher plays major role in play } \\ \text { h }- \text { hospital } & \text { (p.m. group) } & \text { Teacher plays minor role in play }\end{array}$




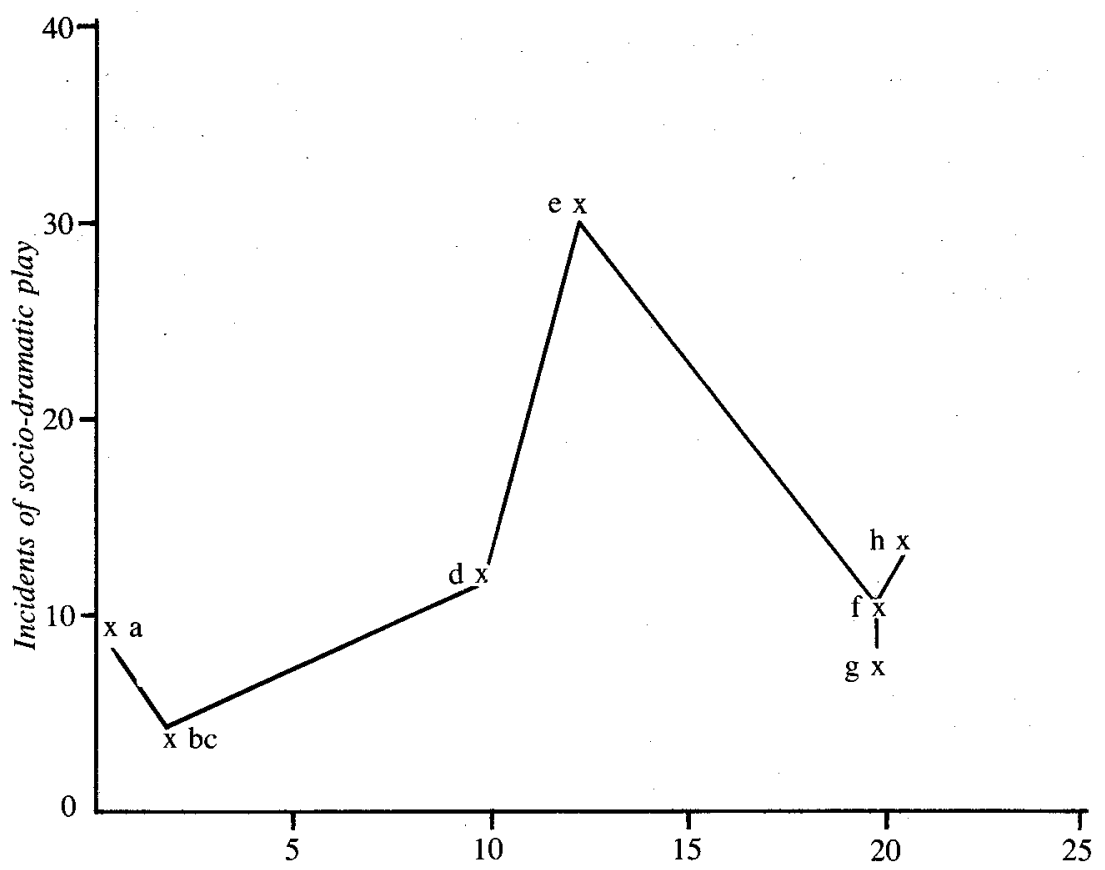

Figure 2. Teacher intervention in socio-dramatic play.

$\begin{array}{clll}\text { KEY } & \text { a - hospital } & \text { (a.m. group) } & \\ \text { b - grocery } & \text { (p.m. group) } & \\ \text { c - grocery } & \text { (a.m. group) } & \\ \text { d - post office } & \text { (a.m. group) } & \\ \text { e - zoo } & \text { (a.m. group) } & \text { English model involved in play } \\ \text { f }- \text { zoo } & \text { (p.m. group) } & \text { Teacher acts as anchor } \\ \text { g- post office } & \text { (p.m. group) } & \text { Teacher plays major role in play } \\ \text { h }- \text { hospital } & \text { (p.m. group) } & \text { Teacher plays minor role in play }\end{array}$

to feed the animals, Kelvin." Sometimes he had difficulty in sustaining the narrative, however, such as when one non-English speaking child (who earlier had seemed not to understand what a zoo was when he was heard saying to himself "zoo, circus?") began to put books in each of the animals' cages. At another point in the play some children began to pull chairs into the area and Robbie shouted out "no chairs allowed." This order was immediately repeated by the non-English speaking children. The chairs were removed, and the theme was continued. The children were heard acknowledging Robbie's leadership by telling each other, "I am helping Robbie."

In the other episodes in which the teacher tried to take on the leader- 
ship role, similar to the one played by Robbie in the zoo, she was less successful in developing the same sense of cohesion in the group and in keeping the play on track. In trying to motivate language and play appropriate to the theme, the teacher would often use questions such as, "What does your rabbit like?" "Easter egg," replied a child supposedly playing with one of the "zoo" animals. Another strategy she used to promote language and play was to model the appropriate behaviour, such as the role of the patient in the hospital, "Dr. Basi thinks I am still sick, you could take my temperature." "What is my blood pressure, Michael?" Then, once she had demonstrated the appropriate behaviour she tried to encourage one of the children to take over, "Are you going to be the patient now, Shauneen?" At other times she played a major role in the play and verbalized her actions for the children so that they would understand the meaning of the words she was using, "I have some letters here: I picked them up from the big mailbox."

In comparing the results illustrated in both the figures, it appears that the teacher plays an important role in stimulating second language learning by intervening verbally in the children's play. Her verbal interaction with the children during their play encourages them to use English, not only with the teacher, but with other children.

The breakdown of all verbal utterances between non-English speaking children, between English and non-English speaking children, and between children and teacher is shown on Table \#1. As the teacher's verbal interaction increases so does the children's, not only with the teacher but also with each other. As can be seen on Table \# 1 there are relatively few incidents of children using their first language during the eight episodes of structured play. Observations of the children's verbal interactions have led us to believe that the opposite occurs during unstructured play. At these times children tend to play in groups with others of the same linguistic background and use their first language to communicate with each other.

On the other hand, the teacher's intervention in play may decrease the amount of socio-dramatic play produced by the children. Teachers, therefore, need to be sensitive as to how much intervention is required by the teacher to stimulate language without interfering in the development of more mature forms of play. A final evaluation of the unit based on the community theme suggested that it may have been too advanced for a group of children without a common language or cultural experience. As a result the children may have had trouble in developing the narrative or script necessary for developing spontaneous play at a more mature level such as that of socio-dramatic play. If this is so, it shows the importance of teachers' developing programs based on the reality of the child's past experience and level of social development. We are 
repeating the experiment again this year with a theme based on food to see if this will improve the children's ability to play at a more mature level.

The overall results of the above study support researchers such as Weikart et al., who state that not all children gain the same benefits from unstructured freeplay typical of play oriented preschool programs. Teachers working with children from different linguistic and cultural backgrounds may need to structure the children's play, being careful not to dominate it, but at the same time be prepared to interact verbally with the children so as to provide an environment that more closely matches the children's linguistic and social developmental needs.

Table 1

Breakdown of Children's and Teachers'

English Language Interactions

\begin{tabular}{|l|c|c|c|c|c|c|c|c|}
\hline & $\begin{array}{c}\text { ESL/ } \\
\text { ESL } \\
1 \text { st 1 }\end{array}$ & $\begin{array}{c}\text { ESL/ } \\
\text { ESL 1 }\end{array}$ & $\begin{array}{c}\text { ESL/ } \\
\text { ENG }\end{array}$ & $\begin{array}{c}\text { ENG/ } \\
\text { ESL }\end{array}$ & $\begin{array}{c}\text { ENG/ } \\
\text { ENG }\end{array}$ & $\begin{array}{c}\text { ESL/ } \\
\text { Teach }\end{array}$ & $\begin{array}{c}\text { ENG/ } \\
\text { Teach }\end{array}$ & $\begin{array}{c}\text { Teach/ } \\
\text { child }\end{array}$ \\
\hline $\begin{array}{l}\text { Post Office } \\
\text { a.m. group }\end{array}$ & 0 & 1 & 4 & 16 & 2 & 2 & 11 & 7 \\
\hline $\begin{array}{l}\text { Post Office } \\
\text { p.m. group }\end{array}$ & 1 & 67 & 0 & 0 & 0 & 34 & 0 & 38 \\
\hline $\begin{array}{l}\text { Grocery } \\
\text { a.m. group }\end{array}$ & 0 & 0 & 1 & 4 & 15 & 0 & 4 & 5 \\
\hline $\begin{array}{l}\text { Grocery } \\
\text { p.m. group }\end{array}$ & 0 & 8 & 9 & 9 & 1 & 2 & 1 & 2 \\
\hline $\begin{array}{l}\text { Hospital } \\
\text { a.m. group }\end{array}$ & 7 & 0 & 1 & 0 & 14 & 0 & 0 & 0 \\
\hline $\begin{array}{l}\text { Hospital } \\
\text { p.m. group }\end{array}$ & 0 & 3 & 12 & 7 & 0 & 8 & 9 & 28 \\
\hline $\begin{array}{l}\text { Zoo } \\
\text { a.m. group }\end{array}$ & 3 & 4 & 30 & 34 & 24 & 16 & 5 & 28 \\
\hline $\begin{array}{l}\text { Zoo } \\
\text { p.m. group }\end{array}$ & 0 & 36 & 10 & 7 & 0 & 24 & 3 & 39 \\
\hline TOTAL & 11 & 119 & 67 & 77 & 56 & 86 & 33 & 147 \\
\hline
\end{tabular}

First languages spoken in each group

morning group

English 6 children

Gujarati 1 child

Cantonese 8 children afternoon group

English $\quad 3$ children

Gujarati 3 children

Cantonese 6 children 


\section{REFERENCES}

Dixon, G. \& Fraser, S. (1986). Teaching Preschoolers in a Multilingual Classroom. Childhood Education, March/April.

Froebel, F. (1897). The education of man. Trans. W. Hailman, New York: Appleton, reprint ed., New York: Kelly, 1970.

Garvey, C. (1974). Some properties of social play. Merrill-Palmer Quarterly, $20,163-180$.

Garvey, C. (1977). Play. Cambridge, Mass.: Harvard University Press.

Garvey, C. and Hogan, R. (1973). Social speech and social interaction: Egocentrism revisited. Child Development, 44, 562-568.

Lee, M. (1984). Strategies for teaching young children: Guides for improving instruction. Early Child Development and Care, 14, 189-200.

Parten, M.B. (1932). Social participation among pre-school children. Journal of Abnormal and Social Psychology, 27, 243-269.

Piaget, J. (1962). Play, dreams and imitation in childhood. New York: Norton.

Rosenblatt, D. (1977). Developmental trends in infanct play. In B. Tizard \& D. Harvey, Eds. Biology of Play. London: Heineman.

Sachs, J., Goldman, J. and Chaille, C. (1984). Planning in pretend play: Using language to coordinate narrative development. In A.D. Pellegrini \& T.D. Yawkey, Eds. The development of oral and written language in social contexts, Vol. XII. New Jersey: Ablex Publishing Co.

Sherrod, K.B., Siewart, L.A. and Cavallaro, S.A. (1984). Language and play maturity in preschool children. Early Child Development and Care, 4, 147160.

Smilansky, S. (1968). The effects of socio-dramatic play on disadvantaged preschool children. New York: John Wiley and Sons.

Weikart, D.P., Epstein, A.S., Scheinhart, L. and Bond, J.T. (1978). The Ypsilanti preschool curriculum demonstration project: Preschool years and longitudinal results. Ypsilanti, Michigan: High/Scope Educational Research Foundation.

Yawkey, T.D. and Miller, T.J. 1984). The language of social play in young children. In A.D. Pelligrini and T.D. Yawkey (Eds.), The development of oral and written language in social contexts: Vol. XII. New Jersey: Ablex Publishing Co.

\section{THE AUTHORS}

Susan Fraser became interested in early childhood education and multilingualism when she taught nursery school in Kenya in the early 1960s. She completed her Master's degree in early childhood education at the University of British Columbia. She has held the position of director of a nursery school in West Vancouver and has been instructor in early childhood education at Douglas College in New Westminster. In the last two years she has been a research associate with the Sexsmith Project, a multicultural preschool research project in Vancouver. The Sexsmith Project was funded by the Secretary of State, Federal Government, Ottawa, Canada. 
Patricia Wakefield is presently Assistant to the Director at the Child Study Centre at the University of British Columbia. She has had many years of experience in the field of English as a Second Language as instructor, teacher trainer and author. In the recent publication, Early Childhood Education for a Multicultural Society (Western Educational Development Group, U.B.C. 1985) she was involved as a contributing author and a member of the editorial board. 